\title{
Overseeding Rhizoma Perennial Peanut Pasture and Hay Fields during the Cool Season ${ }^{1}$
}

Jose Dubeux, Cheryl Mackowiak, Ann Blount, David Wright, and Luana Dantas²

\section{Introduction}

Rhizoma perennial peanut (Arachis glabrata Benth.) is an important hay crop in Florida used for many different livestock systems, including equines, small ruminants, and cattle. This warm-season perennial legume is also a valuable forage option for grazing systems (Dubeux et al. 2018). In addition to adding $\mathrm{N}$ via biological $\mathrm{N}_{2}$ fixation, rhizoma peanut has greater nutritive value than most warm-season perennial grasses. Integrating this legume into grazing systems results in superior livestock performance.

Hay and livestock producers want to know if they can overseed their rhizoma peanut fields with cool-season forages during RPP dormancy. Frequently asked questions include:

- Will it decrease rhizoma peanut regrowth in the following season?

- What will be the most productive cool-season annual species to overseed into RPP?

- Can I use late-maturing forages, such as annual ryegrass and clovers?

\section{Overseeding for Hay}

A field trial at the UF/IFAS North Florida Research and Education Center (UF/IFAS NFREC) in Quincy, FL was conducted over two seasons on a 10-year-old stand of
'Arblick' rhizoma perennial peanut. The growth habit and seasonal yield under hay management of 'Arblick' are comparable to those of 'Ecoturf'. In December 2012 (Year 1), the rhizoma peanut pasture was drilled with cool-season forage seed and fertilized (Table 1). An "empty drill" treatment was included to test the effect of soil disruption on weed pressure. A control without drilling was included as well. Fertilizers were applied in early January 2013 (Table 1). Cool-season forages were harvested on April 8, 2013, and rhizoma peanut was harvested on June 21, 2013, following a weed count. The rhizoma peanut was not fertilized during the summer.

After haying off the rhizoma peanut field in November 2013, we reapplied the cool-season treatments (Year 2); however, instead of using the "empty drill" treatment, we planted Jumbo annual ryegrass (Table 1). We applied fertilizers in early February (Table 2). To compare cool-season forage removal on subsequent rhizoma peanut yield, we harvested half of each cool-season treatment plot in midMarch 2014 and the remaining half in mid-April 2014. All treatments were harvested in June (to track rhizoma peanut growth) and again in late October 2014.

The cool-season small grains performed equally well alone or blended with crimson clover (Figure 1). The clover monoculture produced only about $20 \%$ of the biomass as the grasses; however, no $\mathrm{N}$ fertilizer was applied to this

1. This document is SS-AGR-426, one of a series of the Agronomy Department, UF/IFAS Extension. Original publication date January 2019. Visit the EDIS website at https://edis.ifas.ufl.edu for the currently supported version of this publication.

2. Jose Dubeux, associate professor, Agronomy Department; Cheryl Mackowiak, associate professor, Department of Soil and Water Sciences; Ann Blount, professor; David Wright, professor; and Luana Dantas, student intern, Agronomy Department, UF/IFAS North Florida Research and Education Center; UF/IFAS Extension, Gainesville, FL 32611.

The Institute of Food and Agricultural Sciences (IFAS) is an Equal Opportunity Institution authorized to provide research, educational information and other services only to individuals and institutions that function with non-discrimination with respect to race, creed, color, religion, age, disability, sex, sexual orientation, marital status, national origin, political opinions or affiliations. For more information on obtaining other UF/IFAS Extension publications, contact your county's UF/IFAS Extension office. 
treatment since it had the potential to fix $\mathrm{N}_{2}$. The June 2013 yield of rhizoma peanut was not affected by the previous forage. Weeds tended to be more suppressed by the grass forages (Figure 2). The mixed rye/clover and especially oat/ clover treatments exhibited somewhat higher weed counts than they did when grown as small grain monocultures. This is likely due to the higher seeding rate $(120 \mathrm{lb} / \mathrm{acre}$ small grain) of the monoculture compared to the blend ( 80 $\mathrm{lb} /$ acre small grain). There were some random rye plants that continued to grow after the April harvest. Buyers may find dry rye spikes in rhizoma hay bales to be visually unacceptable (Figure 3).

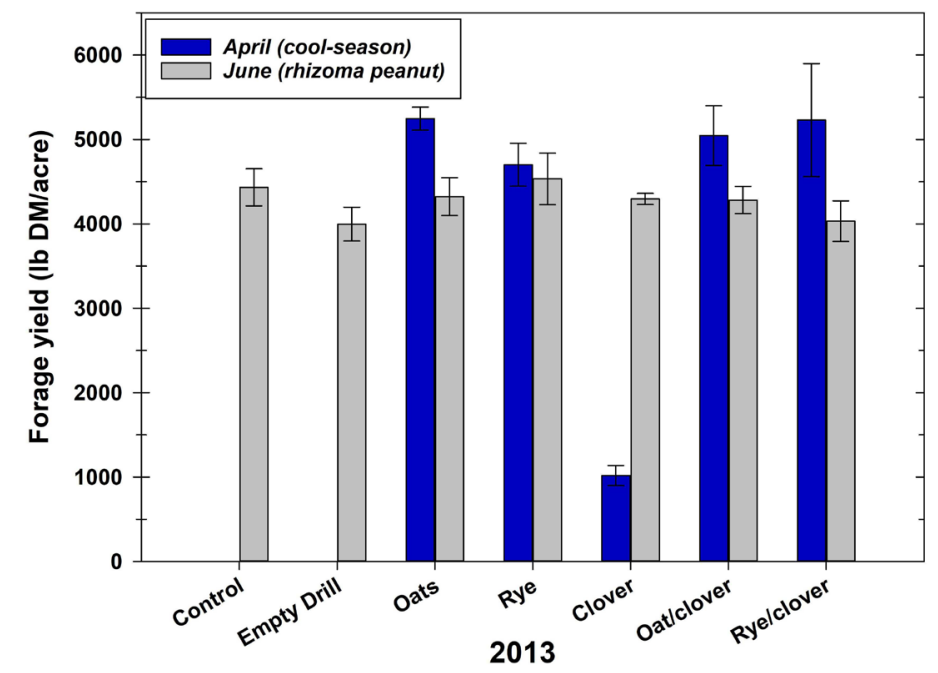

Figure 1. Cool-season forage yields in April 2013 (blue bars) and rhizoma peanut yields in June 2013 (gray bars).

Credits: UF/IFAS

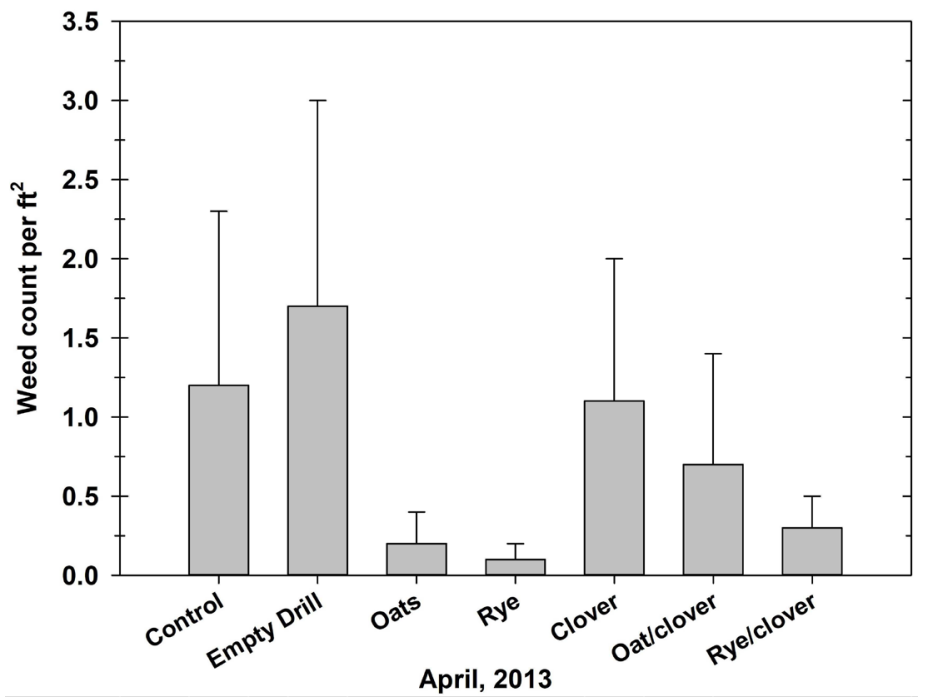

Figure 2. Weed counts from four replicate plots in the first year, April 2013.

Credits: UF/IFAS

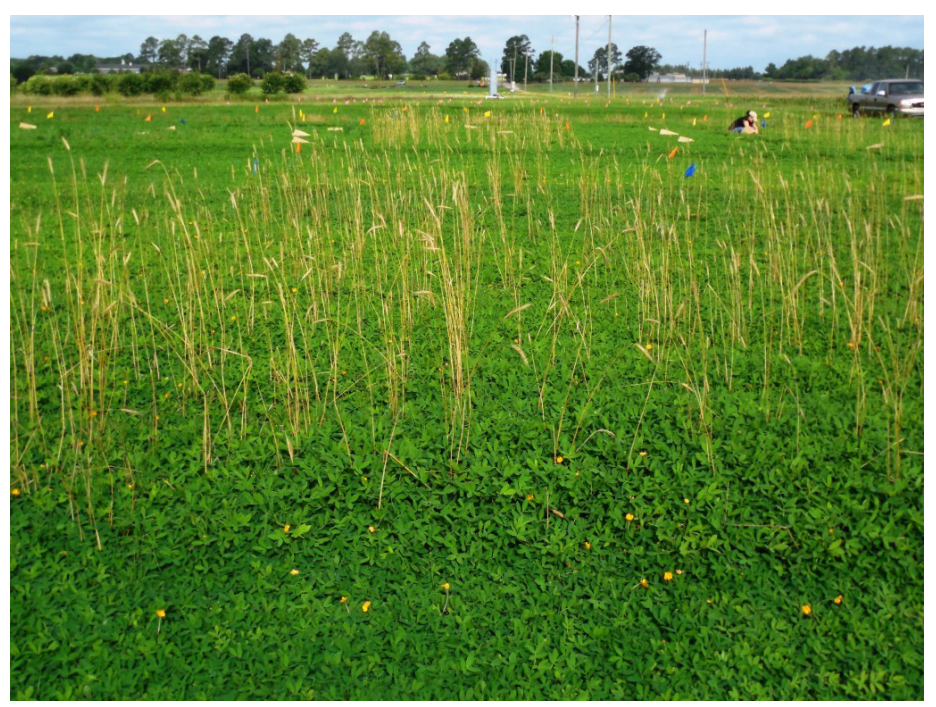

Figure 3. Rye was harvested in April 2013, but unexpected regrowth contaminated the June rhizoma peanut harvest.

Credits: C. Mackowiak, UF/IFAS

We tested two different cool-season forage hay dates (midMarch and mid-April) in 2014 and included an annual ryegrass treatment. Regardless of forage type, waiting until April to cut hay resulted in a large gain in cool-season forage dry matter (Figure 4). Among the forage types, the small grains (rye and oats), with or without clover, had the greatest yield gains. The annual ryegrass yields were about half of the small grain yields, since annual ryegrass tends to mature later than the small grains used in these trials. Clover was lower-yielding in 2013 and 2014. Unless the clover is seeded much earlier (perhaps by mid- to late October), it is not likely to be a good winter cover hay option for rhizoma peanut fields. Additionally, rhizoma peanut dormancy does not begin until mid-November or later (after a heavy frost) in north Florida. An earlier annual ryegrass planting has the same limitations regarding potential competition with rhizoma peanut in the fall. Harvest date did not affect RPP summer yields. However, we found some rhizoma peanut yield differences due to forage treatment. The annual ryegrass treatment resulted in about $24 \%$ more dry matter yield than the clover treatment in the June harvest (Figure 4), and a third of that forage yield was annual ryegrass tissue rather than rhizoma peanut tissue. Annual ryegrass contamination may concern producers who are trying to market high-grade rhizoma peanut hay. Compared to the control treatment, the annual ryegrass treatment resulted in approximately $18 \%$ less rhizoma peanut hay yield in October (Figure 5). With annual ryegrass competition lasting into the early summer, it might depress rhizoma hay yields all season. 


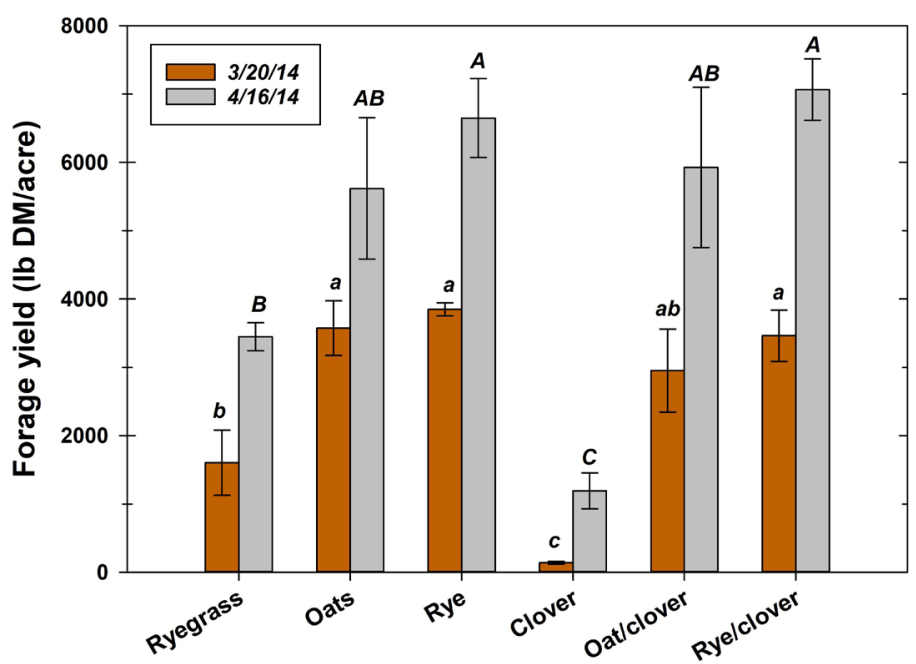

Figure 4. Cool-season forage harvested as hay in March or April 2014. Lowercase letters were used to compare cool-season forage yields for March and uppercase letters were used for April.

Credits: UF/IFAS

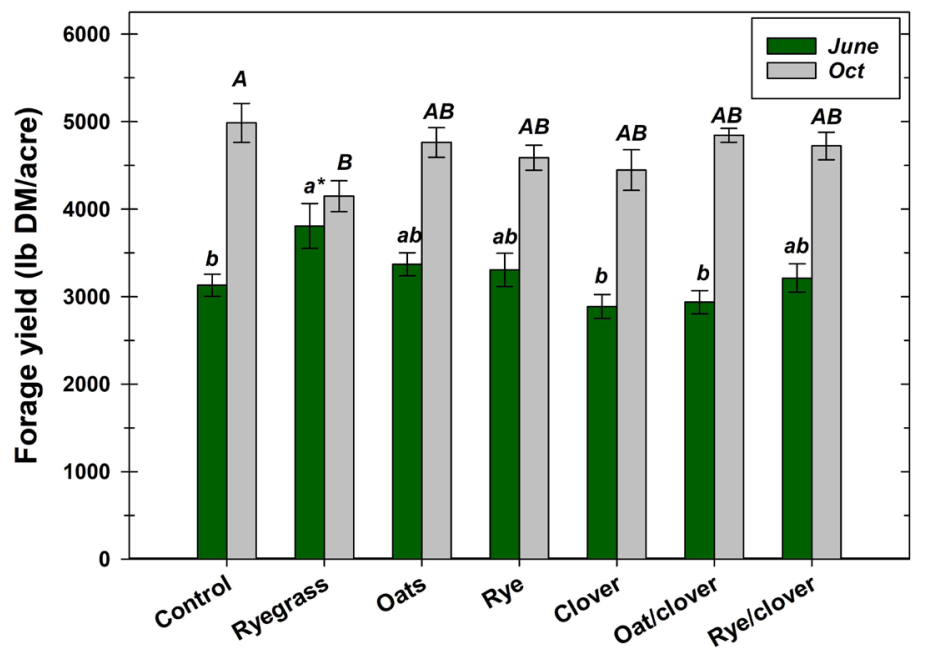

Figure 5. Annual ryegrass contamination comprised approximately a third of the June rhizoma peanut yield value. Lowercase letters were used to compare rhizoma peanut yields for June 2014. Uppercase letters were used for October 2014.

Credits: UF/IFAS

Producers who want to overseed rhizoma perennial peanut with a winter hay crop need to: determine which coolseason forage species and maturity groups will fit within the typical rhizoma peanut dormancy period; determine which cool-season forage hay crops among those available will provide a return on investment; decide if some carryover winter forage residue in the season's first rhizoma peanut hay cutting is acceptable; and consider the potential benefit of suppressing weeds with cool-season small grains rather than applying winter herbicides. Based on the results at UF/IFAS NFREC, planting a relatively early maturing oat variety soon after the first killing frost might be one way to fit a winter forage hay crop into your rhizoma peanut hay operation while also reducing winter herbicide applications.

\section{Overseeding for Grazing}

We initiated a trial at UF/IFAS NFREC in Marianna, FL to assess different overseeding treatments on rhizoma peanut fields, including a control (no overseeding), Prine ryegrass, FL 401 rye, FL 401 rye/Prine ryegrass mix, Prine ryegrass/ crimson/red/ball clover mix, FL 401 rye/crimson/red/ ball clover mix, FL 401 rye/Prine ryegrass/crimson/red/ ball clover mix, and crimson/red/ball clover mix. Table 3 lists seeding rates. The different overseeding treatments were applied on a dormant 'Florigraze' sod using a no-till drill on November 17, 2015, after the stand was mowed to a 2-inch stubble height. We applied $150 \mathrm{lb} / \mathrm{acre}$ of 20-5-20 and $100 \mathrm{lb} / \mathrm{acre}$ of Kmag $\left(22 \mathrm{lb} \mathrm{K} \mathrm{O}_{2}\right.$ /acre, $22 \mathrm{lb}$ S/acre, and $10.8 \mathrm{lb} \mathrm{Mg} / \mathrm{acre})$ to all treatments. Plots were harvested three times: on February 11, March 17, and April 21 of 2016. After the third harvest, plots were fertilized with 300 lb Kmag/acre. On July 22, 2016, we harvested the rhizoma peanut to assess whether overseeding treatments affected regrowth. Frequent harvests were utilized to mimic grazing.

Forage yield varied across the three harvests (Figure 6). As expected, earlier maturing forage types, such as FL 401 rye, produced more dry matter in the first harvest. Treatments with clovers and annual ryegrass produced more biomass later in the season, especially by the third harvest. The optimal forage type or mixtures will depend on the objective of each operation. For grazing operations, mixtures will likely be a good option because of the longer growing season of the combined species, which may help bridge the forage gap during the spring-summer transition.

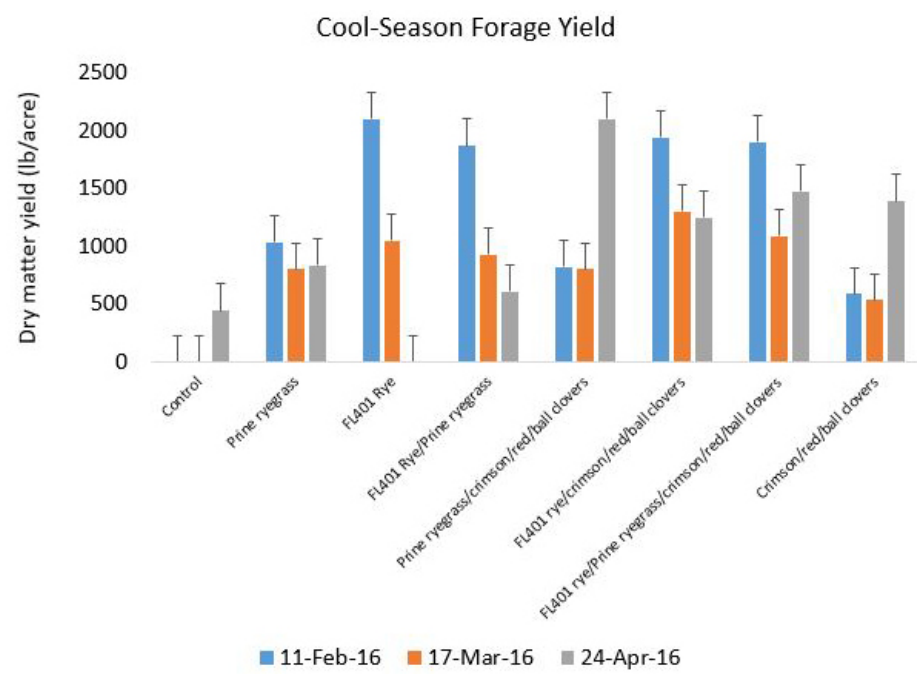

Figure 6. Cool-season forage yield of different overseeding treatments on 'Florigraze' rhizoma peanut. UF/IFAS NFREC in Marianna, FL; 2016. Credits: UF/IFAS 
The rhizoma peanut produced similar yields with the July harvest across all treatments (Figure 7). The results demonstrate the viability of overseeding rhizoma peanut fields with cool-season forages for grazing. Timely harvests of the cool-season forages during the springtime are important. These harvests allow the rhizoma peanut to regrow.

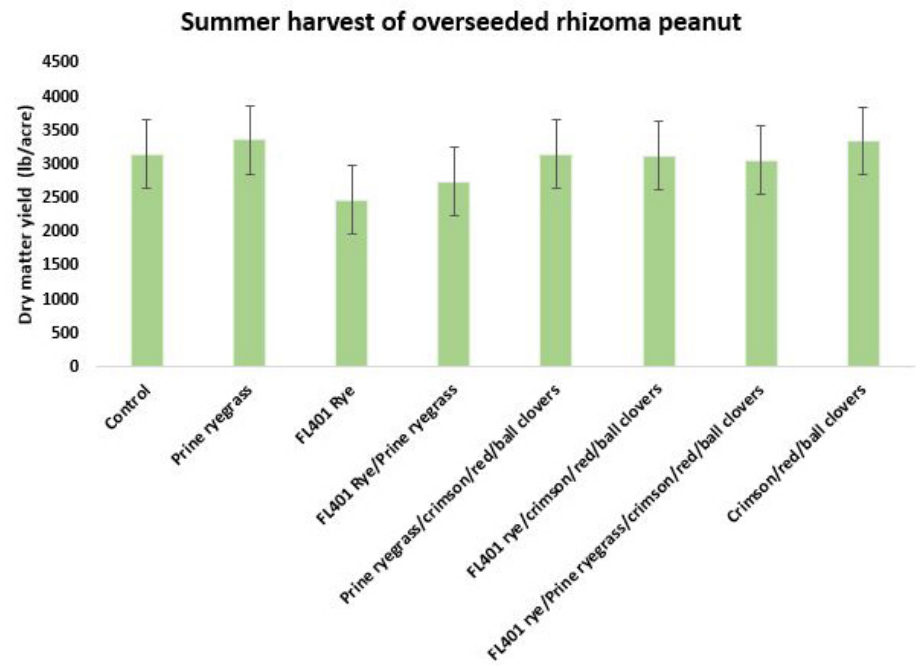

Figure 7. Summer forage yield of 'Florigraze' rhizoma peanut after overseed during the cool season with different forage options. UF/ IFAS NFREC in Marianna, FL; 2016.

Credits: UF/IFAS

We have also been overseeding cool-season forages (i.e., rye-oat and crimson-red-ball clovers) on strip-planted rhizoma peanut in a grazing trial since 2015 as part of another three-year study (Figure 8). The rhizoma peanut summer growth remains vigorous (Figure 8C). However, it is important to make sure the winter forages are sufficiently grazed off in spring, when rhizoma peanut is breaking from winter dormancy (Figure 8B).

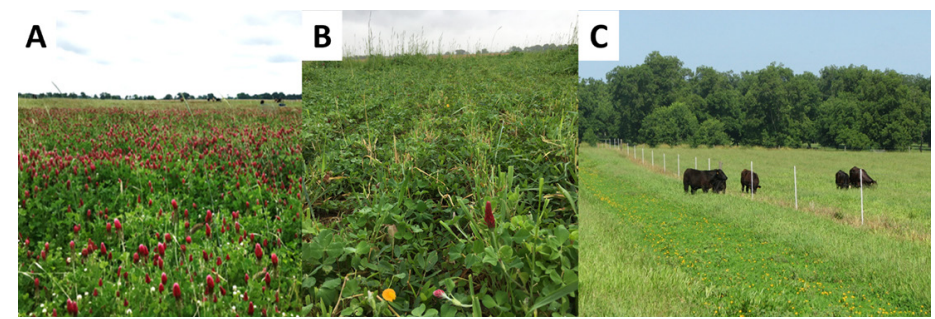

Figure 8. Overseeding of cool-season forages on strip-planted rhizoma peanut in Marianna, FL. A. Cool-season mixture of FL 401 rye-RAM oat-Dixie Crimson-Southern Belle red clover-ball clover. B. Transition period during the spring. $C$. Strip-planted rhizoma peanut growing during the summer.

Credits: Jose Dubeux, UF/IFAS

\section{Conclusion}

Overseeding rhizoma peanut pastures with cool-season forages can be a viable alternative for hay producers in Florida that does not negatively affect summer productivity. However, if the cool-season forages form a dense stand during the spring, it is important to graze it off or remove the excess forage with hay equipment to reduce competition and allow an early regrowth of the rhizoma peanut. The cool-season forage selection should be based on how both the cool-season and summer forages will be utilized (i.e., grazing, hay, or some combination). Our data indicated that 1 ) overseeding did not reduce rhizoma peanut summer regrowth; 2) mixtures of cool-season grasses including small grains and clovers with cool-season legumes were the most productive; and 3) annual ryegrass and clovers can be overseeded on rhizoma peanut without harming the summer harvest, as long as the right management is applied.

\section{Reference}

Dubeux, J., L. E. Sollenberger, J. Vendramini, M. Wallau, A. Blount, L. Garcia-Jimenez, E. Santos, and D. Jaramillo. 2018. Strip-Planting Rhizoma Peanut into Grazing Systems. SS-AGR-421. Gainesville: University of Florida Institute of Food and Agricultural Sciences. http://edis.ifas.ufl.edu/ ag421 
Table 1. Overseeding treatment rates applied to rhizoma peanut over two cool-season years. Source: UF/IFAS NFREC.

\begin{tabular}{|l|c|c|c|c|}
\hline \multicolumn{1}{|c|}{ Overseeding Treatment } & $\begin{array}{c}\text { AGS } \\
\text { Rye }\end{array}$ & $\begin{array}{c}\text { Horizon 201 } \\
\text { Oat }\end{array}$ & $\begin{array}{c}\text { Dixie } \\
\text { Crimson Clover } \\
\text { lb/acre }\end{array}$ & $\begin{array}{c}\text { Jumbo } \\
\text { Annual Ryegrass }\end{array}$ \\
\hline Control & \multicolumn{2}{|c|}{----} \\
\hline Empty drill* & -- & -- & --- & $20^{*}$ \\
\hline Oat & --- & --- & --- & --- \\
\hline Rye & --- & 120 & --- & --- \\
\hline Clover & 120 & --- & 25 & --- \\
\hline Oat/clover & --- & --- & 15 & --- \\
\hline Rye/clover & --- & 80 & 15 & --- \\
\hline
\end{tabular}

*An empty drill was applied as a treatment in Year 1 to test the potential impact of winter weeds caused by soil disturbance. This treatment was replaced by an annual ryegrass treatment in Year 2.

Table 2. Overseeding fertilizer rates applied to rhizoma peanut during the beginning of two cool-season years. Source: UF/IFAS NFREC.

\begin{tabular}{|c|c|c|c|c|c|c|c|c|}
\hline \multirow{2}{*}{$\begin{array}{c}\text { Overseeding } \\
\text { Treatment }\end{array}$} & \multicolumn{2}{|c|}{ Nitrogen (N) } & \multicolumn{2}{|c|}{ Phosphate $\left(\mathbf{P}_{2} \mathbf{O}_{5}\right)$} & \multicolumn{2}{|c|}{ Potash $\left(\mathrm{K}_{2} \mathrm{O}\right)$} & \multicolumn{2}{|c|}{ Sulfur (S) } \\
\hline & Year 1 & Year 2 & Year 1 & Year 2 & Year 1 & Year 2 & Year 1 & Year 2 \\
\hline & & ----י & 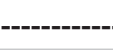 & 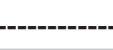 & re-------- & 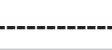 & ------ & \\
\hline Control & --- & --- & --- & --- & --- & --- & --- & --- \\
\hline Empty drill* & --- & 50 & --- & 20 & --- & 40 & --- & 20 \\
\hline Oat & 30 & 50 & --- & 20 & --- & 40 & 10 & 20 \\
\hline Rye & 30 & 50 & --- & 20 & --- & 40 & 10 & 20 \\
\hline Clover & -- & --- & --- & 20 & --- & 40 & 10 & 20 \\
\hline Oat/clover & 30 & 50 & --- & 20 & --- & 40 & 10 & 20 \\
\hline Rye/clover & 30 & 50 & --- & 20 & --- & 40 & 10 & 20 \\
\hline
\end{tabular}

*An empty drill was applied as a treatment in Year 1 to test the potential impact of winter weeds caused by soil disturbance. This treatment was replaced by an annual ryegrass treatment in Year 2.

Table 3. Seeding rates of different overseeding treatments on rhizoma peanut during the cool season. Source: UF/IFAS NFREC in Marianna, FL.

\begin{tabular}{|c|c|c|c|c|c|}
\hline Overseeding Treatment & FL 401 Rye & Prine Ryegrass & Ball Clover & Red Clover & Crimson Clover \\
\hline & (lb/acre) & (lb/acre) & (lb/acre) & (lb/acre) & (lb/acre) \\
\hline \multicolumn{6}{|l|}{ Control } \\
\hline Ryegrass & & 30 & & & \\
\hline Rye & 80 & & & & \\
\hline Rye-ryegrass & 70 & 15 & & & \\
\hline $\begin{array}{l}\text { Ryegrass }+ \text { crimson }+ \text { red }+ \\
\text { ball }\end{array}$ & & 20 & 3 & 6 & 15 \\
\hline Rye + crimson + red + ball & 70 & & 3 & 6 & 15 \\
\hline $\begin{array}{l}\text { Rye-ryegrass + crimson + red } \\
+ \text { ball }\end{array}$ & 70 & 15 & 3 & 6 & 15 \\
\hline Crimson + red + ball & & & 3 & 6 & 15 \\
\hline
\end{tabular}

